\title{
CARBACETAM EFFECT ON BEHAVIORAL REACTIONS IN EXPERIMENTAL ALZHEIMER'S DISEASE
}

\author{
Olga G. KMET ${ }^{1 凶}$, Sergiy V. ZIABLITSEV ${ }^{2}$, Nataliia D. FILIPETS ${ }^{1}$, Taras I. KMET ${ }^{1}$, \\ Xenya V. SLOBODIAN ${ }^{1}$ \\ ${ }^{1}$ Higher State Educational Establishment of Ukraine, „Bukovinian State Medical University“, Chernivtsi, \\ Ukraine \\ ${ }^{2}$ Bogomolets National Medical University, Kiev, Ukraine
}

Received 05 Oct 2018, Accepted 11 Dec 2018

https://doi.org/10.31688/ABMU.2019.54.1.17

\section{Abstract}

Introduction. Considering the inadequate results of the actual treatment, the search for new means of pathogenic therapy of Alzheimer's disease is important.

The objective of the study. To assess the efficacy of new original modulator of gamma-aminobutyric acid (GABA)-ERGIC carbacetam system by the dynamics of parameters of the cognitive ability of rats with Alzheimer's disease.

Materials and methods. Alzheimer's disease was simulated by intraperitoneal introduction of scopolamine hydrochloride (Sigma, USA) during 27 days, in the dose of $1 \mathrm{mg} / \mathrm{kg}$. Beginning with the $28^{\text {th }}$ day of the experiment, carbacetam was introduced intraperitoneal, in the dose of $5 \mathrm{mg} / \mathrm{kg}$ in $1 \mathrm{ml}$ of physiological solution (saline) - once a day during 14 days.

Results. Behavioral reactions of rats with Alzheimer's disease after carbacetam introduction in the „open field" test, were characterized by reduced period of „immobility“, increase motor, orientation-learning activity; in "conditioned passive avoidance reflex" test increased latent period of entering rats into a dark chamber connected to electric current.

\section{Résumé}

Linfluence du carbacetam sur les réactions comportementales dans la maladie d'Alzheimer expérimentale

Introduction. Compte tenu de l'efficacité insuffisante des traitements modernes, la recherche de nouveaux moyens de la thérapie pathogénique de la maladie d'Alzheimer est pertinente.

Le but de l'étude est d'évaluer l'efficacité du nouveau modulateur original du système GABA-ERGIQUE du carbacetam en ce qui concerne la dynamique des modifications des indicateurs des réactions comportementales des rats atteints du modèle de la maladie d'Alzheimer.

Matériaux et méthodes. Le modèle de la maladie d'Alzheimer a été créé par l'administration intra-abdominale pendant 27 jours de chlorhydrate de scopolamine (Sigma, USA) à une dose de $1 \mathrm{mg} / \mathrm{kg}$. à partir du 28e jour de l'expérience ; le carbacetam a été administré par voie intra-péritonéale à une dose de $5 \mathrm{mg} /$ $\mathrm{kg}$ dans $1 \mathrm{ml}$ de solution saline physiologique, une fois par jour pendant 14 jours.

Résultats. Les réactions comportementales des rats atteints de la maladie d'Alzheimer après l'introduction 
Conclusions. Behavior of rats with Alzheimer's disease in „open field“ test after carbacetam introduction during 14 days was characterized by reduced latent period of „immobility“, improvement of motor and orientation-learning activity. It was indicative of decreased anxiety level, improvement of adaptation and cognitive reactions. Increased latent period in conditioned passive avoidance reflex (CPAR) test on the $1^{\text {st }}$ and $14^{\text {th }}$ day of carbacetam introduction reflected more effective retention of the conditioned reflex to electric painful stimulation, and improvement of cognitive ability of rats with Alzheimer's disease respectively, under the influence of the new endogenous modulator of GABA-ERGIC system.

Keywords: scopolamine-induced Alzheimer's diseases, carbacetam, higher nervous activity.

Abbreviations: CNS - central nervous system, GABA - gamma-aminobutyric acid, CPAR - conditioned passive avoidance reflex.

\section{INTRODUCTION}

The group of neurodegenerative disorders of the CNS includes a number of diseases with destructive processes of the brain cells in their base. The diseases differ by their symptoms, duration of pathological process, and localization of damage foci. At the same time, all the neurodegenerative disorders of the brain are united by dementia including its most common type - dementia of Alzheimer's type ${ }^{1,2}$. Alzheimer's disease is most often found among people older than 60-65 yo. The characteristic feature of Alzheimer's disease is the progressive deterioration of memory, thinking processes, information perception, intellectual disorders, lack of ability to take care of oneself, stipulating individual difficulties and social-economic value of the disease ${ }^{3,4}$.

Modern approaches to the treatment of Alzheimer's disease include, first of all, pathogenic therapy. Today, the following agents are used to inhibit the development and decrease the manifestation of the main symptoms of the disease: acetylcholinesterase inhibitors (rivastigmine, galantamine, donepezil); noncompetitive antagonists of NMDA-glutamate receptors (memantine); vasoactive drugs and neurometabolic stimulators (trental, nootropil, cortexin); du carbacetam dans le test «en champ ouvert» étaient caractérisées par la diminution du temps de «'immobilité», par l'augmentation de l'activité motrice ; dans le test du "reflexe conditionnel d'évitement passif» par l'augmentation de la période de latence de l'entré des rats dans une chambre obscure connectée au courant électrique.

Conclusions. Le comportement des rats atteints de la maladie d'Alzheimer dans le test " champ ouvert" après l'introduction, temps de 14 jours, de carbacetam était caractérisé par la diminution de la période latente d'«immobilité», par l'augmentation de l'activité motrice, à titre expérimental et a souligné la diminution du niveau d'anxiété, l'amélioration des réponses adaptatives et cognitives. L'augmentation de la période latente de l'entrée dans le test «reflexe conditionnel d'évitement passif» les 1er et 14e jours depuis l'administration du carbacetam a permis de mieux préserver le reflexe conditionnel pour la stimulation électrolytique, et pour l'amélioration des capacités cognitives des rats atteints de la maladie d'Alzheimer sous l'influence d'un nouveau modulateur endogène du système GABA-ERGIQUE.

Mots-clés: la maladie d'Alzheimer induite par la scopolamine, le carbacetam, l' activité nerveuse supérieure.

monoclonal antibodies of beta-amyloid $(A \beta)$ (bapineuzumab, solanezumab, gantenerumab) ${ }^{5-10}$. Since the existing remedies do not provide desirable results completely, the search for new directions of pathogenic treatment still continues ${ }^{11}$.

It should be noted that gamma-aminobutyric acid is a universal neuro-mediator, influencing the balance between stimulation and inhibition, metabolic processes, energy supply, brain resistance to hypoxia. GABA drugs - nootropic agents possess a wide pharmacological spectrum and are actively indicated to restore integrative activity of the CNS. Due to this fact, investigation of pharmacodynamics of the new modulator of GABA-ERGIC system, original derivative of $\beta$-carbolineum - carbacetam, is rather topical. It was synthesized in L.M. Lytvynenko Institute of Physical-Organic Chemistry and Carbochemistry, the National Academy of Sciences of Ukraine, under the supervision of Doctor of Chemical Sciences S.L. Bogza ${ }^{12}$. Ukrainian scientists determined a correcting effect of carbacetam on the cognitive functions under conditions of experimental craniocerebral injury ${ }^{13}$. Considering the fact that GABA-ERGIC mechanisms play an important role in the pathogenesis of memory deterioration ${ }^{14,15}$, the study of therapeutic properties 
of carbacetam in case of experimental Alzheimer's disease is of certain interest.

The objective of the STUDY was to assess the efficacy of new original modulator of GABA-ERGIC carbacetam system by the dynamics of changes of the behavioral reaction parameters of rats with Alzheimer's disease model.

\section{Materials AND Methods}

The experiments were conducted on nonlinear albino male rats with the body weight of 0.18-0.20 kg ( $\mathrm{n}=21)$, kept under standard vivarium conditions, at the temperature of $18-22^{\circ} \mathrm{C}$ and relative humidity $40-60 \%$, on well-balanced food, with free access to water. The study was conducted according to the main principles of the European Convention for the Protection of Vertebrate Animals used for Experimental and other Scientific Purposes (Strasburg, 1986). First, all the rats were divided into two groups: 1 - control group; 2 - rats with simulated Alzheimer's disease. Considering the common recognition of cholinergic hypothesis concerning Alzheimer's disease in pathogenesis of dementia, the investigation was conducted on rats with scopolamine-induced memory disorders ${ }^{16-18}$. All the rats were divided into two experimental series: I-control $(n=7)$ and II - Alzheimer's disease modeling $(\mathrm{n}=14)$. To simulate the pattern of Alzheimer's disease, scopolamine hydrochloride (Sigma, USA) was introduced intraperitoneally $(\mathrm{i} / \mathrm{p})$ into animals of II series, in the dose of $1 \mathrm{mg} / \mathrm{kg}$, in the form of $0.01 \%$ water solution $(0.5 \mathrm{~mL} / 100 \mathrm{~g})$, once a day, during 27 days. Only injection solution was administered to the animals of I series in the same regimen and under similar conditions of the experiment. Beginning with the $28^{\text {th }}$ day of the experiment, rats of II series were divided by means of blind method into two groups: carbacetam was introduced $\mathrm{i} / \mathrm{p}$ in the dose of $5 \mathrm{mg} / \mathrm{kg}$ in $1 \mathrm{~mL}$ of physiological solution $(\mathrm{n}=7)$ and with administration of $1 \mathrm{~mL}$ physiological solution only $(\mathrm{n}=7)$. The animals of I series (control), in order to preserve identical conditions with the animals of II series, were also administered $1 \mathrm{~mL}$ of physiological solution since the $28^{\text {th }}$ day. Carbacetam belongs to endogenous modulators of GABA-benzodiazepine receptor complex, b-carboline derivatives, and is carboline isoster (1-oxo-3.3.6-trimethyl-1.2.3.4-tetrahydroindolo [2.3-c] quinolines); b-carboline structure is the basis for alkaloids (b-carbolines) isolated from the flower of Syrian rue (Peganum harmala).

For further analysis, the animals of I series were included into the $1^{\text {st }}$ group (control), the animals of II series with administration of physiological solution only - to the $2^{\text {nd }}$ group, and the animals of II series with carbacetam introduction - to the $3^{\text {rd }}$ group. According to the literature, the range of doses of the examined drug varies from 3 to 20 $\mathrm{mg} / \mathrm{kg}^{19}$. Carbacetam doses were used considering Methodical Recommendations on experimental study of drugs with nootropic type of action ${ }^{20}$. The dose selected was used by other scientists to examine anti-hypoxic, anti-ischemic carbacetam effects under other experimental conditions ${ }^{21}$.

The cognitive ability of rats was assessed by the indices of „open field“ and CPAR tests ${ }^{22-24}$. To conduct "open field“ test, the chamber with plastic walls of $40 \mathrm{~cm}$ high was used. The floor of the chamber was lined into equal squares, with openings imitating holes on the concurrence of lines. On the $14^{\text {th }}$ days after carbacetam was introduced, the rats from all the groups were placed in the center of the chamber and the time of ,immobility" adaptation period - latent period - was registered. After that, their active behavior was observed. The following indices (number) were registered: motor activity - crossed squares; orientation-learning activity - vertical positions, examination of holes; emotional reactions - grooming (washing), fecal bolus (defecation), and urination.

To assess memory by CPAR test, the chamber consisting of light and dark units, connected together by an opening imitating a hole, was used. The floor in the dark unit was connected to electric current. The rats were placed into the light unit on the $28^{\text {th }}$ day of the experiment, before carbacetam introduction (groups 1, 2; I series); in 1 and 14 days after carbacetam introduction (groups 1-3; II and III series). After the latent period - time interval when rats were in the light unit - they went to the dark unit, the opening was closed and the limbs of rats were stimulated by stabilized electric current of $0.8 \mathrm{~mA}$ during 15 seconds (electric painful simulation). The time of the latent period was registered, the dynamics of its changes informed about formation and retention of the conditioned reflex. According to the terms of CPAR test, the rats without expressed hole-board reflex, those with latent period of entrance into the dark unit was more than 3 minutes, and those trying to enter the dark unit again, were removed from the experiment.

Statistical analysis was performed by the program Statistica 8.0, the differences were considered statistically significant when $p \leq 0.05$.

\section{Results AND discussion}

The results of the „open field“ test presented in Table 1 enable to assess spontaneous motor and learning activity of rats. Under conditions of the test, 
Table 1. Carbacetam effect on motor, orientation-learning and emotional activity of rats with scopolamine-induced Alzheimer's disease in ,open field“ test, $M \pm m, n=7$

\begin{tabular}{|c|c|c|c|}
\hline Indices & Control & Model of Alzheimer's disease & $\begin{array}{c}\text { Model of Alzheimer's dis- } \\
\text { ease + carbacetam }\end{array}$ \\
\hline \multicolumn{4}{|c|}{ Period of immobility } \\
\hline Latent period (adaptation time), C & $10.6 \pm 1.1$ & $\begin{array}{l}16.8 \pm 1.57 \\
\mathrm{P}<0.05\end{array}$ & $\begin{array}{c}13.0 \pm 0.82 \\
P_{1}=0.05\end{array}$ \\
\hline \multicolumn{4}{|c|}{ Motor activity } \\
\hline Number of crossed squares & $22.6 \pm 2.29$ & $\begin{array}{c}13.7 \pm 1.11 \\
\mathrm{P}<0.05\end{array}$ & $\begin{array}{c}17.7 \pm 0.75 \\
P_{1}<0.05\end{array}$ \\
\hline \multicolumn{4}{|c|}{ Orientation-learning activity } \\
\hline Positions & $8.6 \pm 1.51$ & $\begin{array}{l}3.0 \pm 0.82 \\
\mathrm{P}<0.05\end{array}$ & $\begin{array}{l}7.1 \pm 1.22 \\
\mathrm{P}_{1}<0.05\end{array}$ \\
\hline Openings & $11,7 \pm 1,11$ & $\begin{array}{c}6,4 \pm 0,98 \\
P<0,01\end{array}$ & $\begin{array}{c}9,9 \pm 0,90 \\
P_{1}<0,05\end{array}$ \\
\hline \multicolumn{4}{|c|}{ Emotional reactions } \\
\hline Grooming & $7.1 \pm 0.90$ & $\begin{array}{l}2.7 \pm 0.75 \\
\mathrm{P}<0.01 \\
\end{array}$ & $\begin{array}{l}4.3 \pm 0.69 \\
\mathrm{P}<0.05\end{array}$ \\
\hline Urination & $2.8 \pm 0.53$ & $1.4 \pm 0.48$ & $1.3 \pm 0.49$ \\
\hline Fecal bolus & $1.3 \pm 0.48$ & $0.7 \pm 0.48$ & $1.4 \pm 0.53$ \\
\hline
\end{tabular}

Notes: $\mathrm{P}$ - statistical significance in comparison of mean values with the control (the $1^{\text {st }}$ group); $\mathrm{P}_{1}$ statistical significance in comparison of the $2^{\text {nd }}$ and $3^{\text {rd }}$ groups.

in the $2^{\text {nd }}$ group duration of the adaptation latent period was $58.5 \%$ longer as compared with the control $(\mathrm{P}<0.05)$, while in rats of the $3^{\text {rd }}$ group this index in comparison with the $2^{\text {nd }}$ group was $22.7 \%$ lower $\left(\mathrm{P}_{1}=0.05\right)$, and did not differ from that of the control.

Peculiarities of the test are light open space and new surroundings provoking certain tension and behavioral changes of rats. Increased latent period of adaptation in rats with Alzheimer's disease is indicative of an increased risk: confusion, fear, disorientation in the strange surroundings. At the same time, reduction of this interval of immobility after carbacetam introduction to rats with Alzheimer's disease is indicative of the activation of natural adaptive reactions to unusual conditions.

Motor ability of rats with Alzheimer's disease decreased: the number of crossed squares in the $2^{\text {nd }}$ group decreased by $39.4 \%(\mathrm{P}<0.05)$. In the $3^{\text {rd }}$ group, this index increased by $29.2 \%$, that is indicative of improvement of horizontal motor activity due to inhibition of psychological tension under carbacetam effect.

A kind of orientation-learning behavior of rats is the frequency of vertical positions (rising on the hind legs) and examination of the openings. Compared with the $1^{\text {st }}$ group, in the $2^{\text {nd }}$ group the frequency of vertical positions decreased by $65.1 \%(\mathrm{P}<0.05)$, and the number of the examined openings decreased by $45.3 \%(\mathrm{P}<0.05)$. Carbacetam improved considerably the vertical motor activity of rats with Alzheimer's disease. Under carbacetam effect, the above indices increased by $136.7 \%$ and $54.7 \%\left(\mathrm{P}_{1}<0.05\right)$ in both cases. The results obtained inform about carbacetam ability to decrease anxiety level and improve cognitive activity of rats with Alzheimer's disease.

Emotional reactions are an important characteristic of animal behavior in „open field“ (Table 1). Grooming - cosmetic behavior - is the parameter of both comfort and stressful situation, and it was characterized by $62 \%(\mathrm{P}<0.01)$ decreased number of washing in rats from the $2^{\text {nd }}$ group. Under carbacetam effect, in the $3^{\text {rd }}$ group the grooming parameter remained lower than that of the control value of the $2^{\text {nd }}$ group, although the difference decreased and became $39.5 \%(\mathrm{P}<0.05)$. Further analysis of vegetative behavior did not find changes in the amount of urination and fecal bolus.

Assessment of cognitive ability by CPAR test showed that, in the control group of the rats, stable reflex was formed in response to painful simulation with electric current (Table 2). Thus, comparison of the duration of the latent period in the $1^{\text {st }}$ group with the $2^{\text {nd }}$ and $3^{\text {rd }}$ ones determined increased interval one day after the first entrance of rats into a dark chamber, as compared with the values before carbacetam introduction (2.8 times as much; $\mathrm{P}<0.05)$. On the $14^{\text {th }}$ day, the difference with the index of the $1^{\text {st }}$ group was less $(1.6$ times as much; $\mathrm{P}<0.05$ ).

Further analysis of the test results indicated CPAR formation after electric painful simulation of rats with Alzheimer's disease (Table 2). 24 hours after the moment of electric current simulation, the latent period increased with $19.9 \%$. However, deterioration 
Table 2. Carbacetam effect on the latent period of entrance into the dark unit of rats with scopolamine-induced Alzheimer's disease in CPAR test, $\mathrm{M} \pm \mathrm{m}$.

\begin{tabular}{|c|c|c|c|}
\hline \multirow{8}{*}{$\begin{array}{c}\text { Latent period of } \\
\text { entrance into the dark } \\
\text { unit, } C\end{array}$} & \multicolumn{3}{|c|}{ Before carbacetam administration, I series } \\
\hline & Control, $\mathrm{n}=7$ & \multicolumn{2}{|c|}{ Model of Alzheimer's disease, $n=14$} \\
\hline & $60.6 \pm 4.72$ & \multicolumn{2}{|c|}{$58.3 \pm 3.95$} \\
\hline & \multicolumn{3}{|c|}{1 day after carbacetam administration, II series } \\
\hline & Control, $n=7$ & $\begin{array}{l}\text { Model of Alzheimer's } \\
\text { disease, } n=7\end{array}$ & $\begin{array}{c}\text { Model of Alzheimer's disease + } \\
\text { carbacetam, } n=7\end{array}$ \\
\hline & $\begin{array}{l}169.4 \pm 1.14 \\
P<0.0001\end{array}$ & $\begin{array}{l}69.9 \pm 1.35 \\
\mathrm{P}_{1}<0.05 \\
\mathrm{P}_{2}<0.0001\end{array}$ & $\begin{array}{l}85.3 \pm 1.50 \\
\mathrm{P}_{2}<0.001 \\
\mathrm{P}_{3}<0.001\end{array}$ \\
\hline & \multicolumn{3}{|c|}{14 days after carbacetam administration, III series } \\
\hline & $\begin{array}{l}99.9 \pm 1.41 \\
P<0.001\end{array}$ & $\begin{array}{c}34.4 \pm 1.62 \\
\mathrm{P}_{1}<0.01 \\
\mathrm{P}_{2}<0.001\end{array}$ & $\begin{array}{c}130.3 \pm 1.11 \\
P_{2}<0.001 \\
P_{3}<0.0001\end{array}$ \\
\hline
\end{tabular}

Notes: statistical significance of differences: $\mathrm{P}$ - in comparison of the $1^{\text {st }}$ group with the $2^{\text {nd }}$ and $3^{\text {rd }}$ ones; $\mathrm{P}_{1}$ - in comparison of the $1^{\text {st }}$ group with the $2^{\text {nd }}$ group; $\mathrm{P}_{2}-$ in comparison of the $1^{\text {st }}$ group with the $3^{\text {rd }}$ one; $\mathrm{P}_{3}-$ in comparison of the $2^{\text {nd }}$ and $3^{\text {rd }}$ groups.

of memory and CPAR inhibition on the $14^{\text {th }}$ day after simulation of Alzheimer's disease were evidenced by a reduced interval of entrance time into the dark unit on $41 \%$ and $50.8 \%$, respectively, to the indices of I and II series. At the same time, the dynamics of changes in II and III series was characterized by $58.7 \%$ and $65.6 \%$ decrease of the latent period, compared with the appropriate control indices, and thus evidenced the fact of progressive deterioration of memory in rats with Alzheimer's disease.

24 hours after carbacetam administration, the interval of entrance into the dark unit in the $3^{\text {rd }}$ group remained lower than that of the $1^{\text {st }}$ one in II series and the difference was $49.7 \%(\mathrm{P}<0.01)$. At the same time, the $22 \%$ increase of the latent period in rats from the $3^{\text {rd }}$ group is indicative of a potential ability of carbacetam to improve cognitive processes under conditions of the experiment. The results of the $3^{\text {rd }}$ group evidenced the probability of this suggestion. After carbacetam administration during 14 days, the dynamics of changes was characterized by increased latent period by 3.8 and 1.3 times compared with the $1^{\text {st }}$ and $2^{\text {nd }}$ groups, respectively ( $\mathrm{P}<0.05$ in both cases). Improvement of memory under carbacetam effect is manifested in rats with Alzheimer's disease by the ability to inhibit the natural behavior, to avoid repeated painful simulation.

Therefore, carbacetam, under adverse conditions of „open field“ and CPAR tests, produced positive changes in the indices of motor and orientation-learning activity in rats with Alzheimer's disease, which characterize the levels of adaptation, stressful situation, cognitive activity, and memory. It should be noted that carbacetam is an endogenous modulator of GABA-ERGIC system, with determined antioxidant properties. Examination of the pro-oxidant and anti-oxidant systems in the tissues of the heart, lungs, liver, under conditions of multiple trauma determined considerable anti-oxidant properties of carbacetam ${ }^{25}$, which is one of the mechanisms of neuroprotective action of carbacetam evidenced by morphological examinations ${ }^{26}$. Correcting effect of carbacetam on the pro-oxidant and anti-oxidant balance in the brain with experimental Alzheimer's disease can be logically suggested, that is the prospect for further studies.

\section{Conclusions}

The behavior of rats with scopolamine-induced Alzheimer's disease in „open field“ test, after carbacetam administration in the dose of $5 \mathrm{mg} / \mathrm{kg}(14$ days), is characterized by a decreased latent period of „immobility", increased motor, orientation-learning activity, and is indicative of reduced anxiety level, improvement of adaptive and cognitive reactions.

After carbacetam administration during 14 days, reduced grooming index was not resumed and the frequency of vegetative reactions did not change fecal bolus and urinates - which indicates the lack of carbacetam effect on the emotional degree of rats with Alzheimer's disease.

The increased latent period of entrance into the dark unit on the $1^{\text {st }}$ and $14^{\text {th }}$ day of carbacetam introduction reflects a more effective retention of the conditioned passive avoidance reflex to electric painful stimulation, and improvement of cognitive ability of rats with Alzheimer's disease respectively, under the influence of the new endogenous modulator of GABA-ERGIC system. 


\section{Compliance with Ethics Requirements:}

„The authors declare no conflict of interest regarding this article"

"The authors declare that all the procedures and experiments of this study respect the ethical standards in the Helsinki Declaration of 1975, as revised in 2008(5), as well as the national law."

"All institutional and national guidelines for the care and use of laboratory animals were followed"

"No funding for this study"

\section{References}

1. Niu H, Alvarez-Alvarez I, Guillen-Grima F, Aguinaga-Ontoso I. Prevalence and incidence of Alzheimer's disease in Europe: A meta-analysis. Neurologea 2017; 32(8):523-532.

2. Robinson L, Tang E, Taylor JP. Dementia: timely diagnosis and early intervention. BMJ 2015;350:h3029.

3. Kandimalla R, Reddy PH. Therapeutics of neurotransmitters in Alzheimer's disease. J Alzheimers Dis 2017; 57(4):1049_ 1069.

4. Robinson M, Lee BY, Hane FT. Recent progress in Alzheimer's disease research, part 2: Genetics and epidemiology. JAlD 2017; 57(2):317-330.

5. Silva da CB, Pot A, Elifio-Esposito S, et al. Effect of donepezil, tacrine, galantamine and rivastigmine on acetylcholinesterase inhibition in Dugesia tigrina. Molecules 2016, 21(1):53.

6. Lebois EP, Schroeder JP, Esparza TJ, et al. Disease-modifying effects of $\mathrm{M}_{1}$ muscarinic acetylcholine receptor activation in an Alzheimer's disease mouse model. ACS Chem Neurosci 2017; 8(6):1177-1187.

7. Blanco-Silvente L, Castells X, Saez M, et al. Discontinuation, efficacy, and safety of cholinesterase Inhibitors for Alzheimer's disease: a meta-analysis and meta-regression of 43 randomized clinical trials enrolling 16106 patients. IJNP 2017; 20(7):519-528.

8. Mota SI, Ferreira IL, Rego AC. Dysfunctional synapse in Alzheimer's disease - a focus on NMDA receptors. Neuropharmacology 2014; 76(PtA):16-26.

9. Loureneo CF, Ledo A, Dias C, Barbosa RM, Laranjinha J. Neurovascular and neurometabolic derailment in aging and Alzheimer's disease. Front Aging Neurosci 2015;7:103.

10. Rygiel K. Novel strategies for Alzheimer's disease treatment: An overview of anti-amyloid beta monoclonal antibodies. Indian J Pharmacol 2016; 48(6):629-636.

11. Colligris P, Jesus M, Lara P, Colligris B, Pintor J. Ocular manifestations of Alzheimer's and other neurodegenerative diseases: the prospect of the eye as a tool for the early diagnosis of Alzheimer's disease. J Ophthalmol 2018; 8538573.
12. Bogza SL. New heterocyclic systems for new drugs. Nauka innov 2015; 11(6):85-93.

13. Ziablitsev SV, Starodubska OO, Bogza SL. Carbacetam influence on cognitive disturbances in experimental brain injury, possible vasopressin role. Trauma 2017; 18(2):53-58.

14. Li Y, Sun H, Chen Z, Xu H, Bu G, Zheng H. Implications of GABAergic neurotransmission in Alzheimer's disease. Front Aging Neurosci 2016; 8:31.

15. Mandai PK, Kansara K, Dabas A. The GABA - working memory relationship in Alzheimer's disease. JADR 2017; 1(1):43-45.

16. Gilles C, Ertle S. Pharmacological models in Alzheimer's disease research. Dialogues Clin Neurosci 2000; 2(3):247-255.

17. Ozarowski M, Mikolajczak PL, Bogacz A, at al. Rosmarinus officinalis L. leaf extract improves memory impairment and affects acetylcholinesterase and butyrylcholinesterase activities in rat brain. Fitoterapia 2013;91:261-271.

18. Mufson EJ, Counts SE, Perez SE, Ginsberg SD. Cholinergic system during the progression of Alzheimer's disease: therapeutic implications. Expert Review of Neurotherapeutics 2008;8(11):1703-1718.

19. Zhuravsky AV. The cerebroprotective properties of adamantly containing diamins [abstract]. Kyiv, UAP; Institute of Pharmacology and Toxicology of the Academy of Medical Sciences of Ukraine; 2007. 19.

20. Voronina TA, Ostrovskaya PU, Garibova TL. Guidelines for the experimental study of drugs with nootropic type of action. Guidelines for conducting preclinical studies of drugs. Under total ed. Mironov AN. Part 1, M.: Grief and K. 2012; 276-296. [Russian].

21. Zyablytsev SV, Starodubska OO, Bogza SL. Analysis of the neurologic deficit under the traumatic brain injury and methods of its correction. J Educ Health Sport 2017; 7(1):525-533.

22. Shilova IV, Suslov NI. Nootropic effect of meadowsweet (Filipendula vulgaris) extracts. Bull Exp Biol Med 2015;158(5):659-63.

23. Sayapina NV, Sergievich AA, Kuznetsov VL. at all. Influence of multi-walled carbon nanotubes on the cognitive abilities of Wistar rats. Exp Ther Med. 2016;12(3):13111318.

24. Singh V, Kahol A, Singh IP, Saraf I, Shri R. Evaluation of anti-amnesic effect of extracts of selected Ocimum species using in-vitro and in-vivo models. J Ethnopharmacol 2016;19 3:490-499.

25. Kozak DV. Effect of carbacetam on antioxidant and prooxidant balance of heart, lungs and liver tissues in polytrauma dynamic. Spit hirurgiya. Journal of L.Ya. Kovalchuk 2014;1(65):40-42. [Ukrainian].

26. Ziablitsev SV, Starodubska OO, Dyadyk OO. Carbacetam effect on processes of neurodestruction in hippocampus during experimental traumatic brain injury. Morphologia 2017;11(2):12-18 